\title{
Determination of Corrosion of Steel Embedded in Alkali Activation of a Binary Mixture
}

\author{
W. Aperador ${ }^{*}$, J. Duque, E. Delgado \\ School of Engineering, Universidad Militar Nueva Granada, Bogotá-Colombia \\ "E-mail: g.ing.materiales@gmail.com
}

doi: $10.20964 / 110436$

Received: 3 February 2016 / Accepted: 22 February 2016 / Published: 1 April 2016

\begin{abstract}
In order to evaluate the use of structural concrete conventional different mixtures with different components were made to Portland cement, such as fly ash and steel slag, cementitious materials were mixed in binary form and in different percentage. Degradation was determined against corrosion phenomena due to permanent chloride attack by wetting and drying cycles. Electrochemical techniques used for evaluation corresponding to potential corrosion and electrochemical impedance spectroscopy. The results indicate the trend of concrete mixed with fly ash and steel slag, to present potential of anodic oxidation corrosion. The results of the electrochemical characterization comparatively describe concrete containing Portland cementing a slightly more porous and permeable material, which makes it more susceptible to attack by chlorides.
\end{abstract}

Keywords: fly ash, steel slag, chloride ion, corrosion.

\section{$\underline{\text { FULL TEXT }}$}

(C) 2016 The Authors. Published by ESG (www.electrochemsci.org). This article is an open access article distributed under the terms and conditions of the Creative Commons Attribution license (http://creativecommons.org/licenses/by/4.0/). 